\title{
Deoxyribonucleic Acid Homologies of Lactobacillus amylophilus and Other Homofermentative Species
}

\author{
LAWRENCE K. NAKAMURA \\ Northern Regional Research Center, U.S. Department of Agriculture, Peoria, Illinois 61604 \\ The deoxyribonucleic acid (DNA) relatedness between a newly described, \\ homofermentative species, Lactobacillus amylophilus, and a broad spectrum of \\ homofermentative lactobacilli was determined. A low range of DNA reassociation \\ levels (5 to $33 \%$ ) was observed between $L$. amylophilus and those species $(L$. \\ amylovorus, $L$. bulgaricus, $L$. casei, $L$. coryniformis, $L$. delbrueckii, $L$. helveti- \\ cus, L. salivarius, and $L$. xylosus) with which it shared one or more phenotypic \\ characteristics (such as the production of mainly $\mathrm{L}-(+)$-lactic acid from glucose, \\ hydrolysis of starch, the sugar fermentation pattern) or which had a guanine plus \\ cytosine content of $45 \mathrm{~mol} \%$. A lack of DNA relatedness (6 to $20 \%$ reassociation) \\ was noted between $L$. amylophilus and 10 other homofermentative lactobacilli. A \\ DNA reassociation of 90 to $98 \%$ was measured among the tested strains of $L$. \\ amylophilus. Purified cell walls of $L$. amylophilus contained alanine, aspartic \\ acid, glutamic acid, and lysine, but no diaminopimelic acid. The low DNA \\ relatedness indicated that the $L$. amylophilus strains were not highly related \\ genetically to the established homofermentative species and, hence, that they \\ represent strains of a distinct genospecies.
}

Earlier, we described a new species, Lactobacillus amylophilus, that hydrolyzed starch and produced mainly L-(+)-lactic acid homofermentatively (14). The establishment of the new species was based on phenotypic characterization only. To confirm that the organism was a genotypic as well as a phenotypic species and to investigate its possible relationship to lactobacilIi with similar characteristics, deoxyribonucleic acid (DNA) reassociation studies were performed.

The new species, of which substantial numbers of cells were present in all swine waste-corn fermentations examined, elaborated extracellular amylolytic enzymes to facilitate starch metabolism. The specific epithet, amylophilus, was given to indicate the capacity to ferment starch. Because the name Lactobacillus amylophilus Nakamura and Crowell was not included on the Approved Lists of Bacterial Names (19), it was not considered to be validly published as of 1 January 1980 . However, the name has subsequently been validated by being announced in the International Journal of Systematic Bacteriology (13).

\section{MATERIALS AND METHODS}

Bacterial strains. The bacterial strains used in this study are listed in Table 1 . The strains were provided by the Agricultural Research Culture Collection maintained at the Northern Regional Research Center. Strains NRRL B-4538, B-4539, B-4540, and B-4542 are strains of another recentiy described starch-hydrolyzing species, L. amylovorus, isolated from several different cattle waste-corn fermentations (12). The sources of the L. amylophilus strains also were several different swine waste-corn fermentations. Working stocks were grown for 24 to $48 \mathrm{~h}$ in MRS agar (5) stabs at appropriate temperatures and stored at $4{ }^{\circ} \mathrm{C}$. For DNA extraction and cell wall preparation, cultures were grown in MRS broth.

DNA purification and renaturation. DNA was extracted and purified by a modification of Marmur's method (10). The modification involved the use of hydroxyapatite (Bio-Gel HTP, Bio-Rad Laboratories) chromatography (9) to produce highly purified DNA preparations. The purity and quality of each DNA preparation were checked by monitoring the absorbancy ratio at $260 / 280 \mathrm{~nm}(1.8$ to 1.9$)$ and at $260 / 230 \mathrm{~nm}$ (2.0 to 2.3) as described by Marmur (10) and by melting $\left(T_{m}\right)$ curves, which include hyperchromicity values from 38 to $40 \%$ (8).

In preparation for renaturation studies, DNA was sheared by two passages through a French pressure cell at $10,000 \mathrm{lb} / \mathrm{in}^{2}$. After filtration through a $0.45-\mu \mathrm{m}$ membrane (Millipore Corp.), the sheared DNA solution was dialyzed exhaustively against a solution containing $5 \mathrm{ml}$ of SSC $(0.1 \mathrm{M} \mathrm{NaCl}-0.015 \mathrm{M}$ trisodium citrate, $\mathrm{pH}$ 7.0) per liter of $0.001 \mathrm{M}$ ethylenediaminetetraacetate. After dialysis, the DNA solution was dried by freeze-drying. The dried material was dissolved in $2 \mathrm{ml}$ of double-distilled water.

The kinetics of DNA renaturation were measured in reaction mixtures that contained $0.3 \mathrm{ml}$ of $10 \times \mathrm{SSC}$, $0.2 \mathrm{ml}$ of dimethyl sulfoxide, approximately $75 \mu \mathrm{g}$ of DNA, and double-distilled water to bring the volume to $1 \mathrm{ml}$. In reaction mixtures containing two different DNAs, the amounts (about $37.5 \mu \mathrm{g}$ ) of the nucleic acids were adjusted to differ by no more than $0.15 \mu \mathrm{g}$. The reaction mixtures were placed in 0.4-ml quartz cuvettes that were sealed with Teflon-lined stoppers. Denaturation and renaturation were effected and mon- 
TABLE 1. List of strains used in this study.

\begin{tabular}{|c|c|c|c|c|}
\hline \multirow{2}{*}{$\begin{array}{c}\text { Serial } \\
\text { no. }\end{array}$} & \multirow{2}{*}{ Laboratory no. } & \multicolumn{2}{|l|}{ Received as: } & \multirow{2}{*}{ Source } \\
\hline & & Name & Strain & \\
\hline 1 & NRRL B-4495 ${ }^{a}$ & L. acidophilus & ATCC 4356 & $\mathrm{ATCC}^{b}$ \\
\hline 2 & NRRL B-4435 & L. amylophilus & & Original isolate \\
\hline 3 & NRRL B-4436 & L. amylophilus & & Original isolate \\
\hline 4 & NRRL B- $4437^{a}$ & L. amylophilus & & Original isolate \\
\hline 5 & NRRL B-4438 & L. amylophilus & & Original isolate \\
\hline 6 & NRRL B-548 & L. bulgaricus & ATCC 7943 & ATCC \\
\hline 7 & NRRL B-734 & L. bulgaricus & ATCC 7994 & ATCC \\
\hline 8 & NRRL B-1909 & L. bulgaricus & ATCC 12278 & ATCC \\
\hline 9 & NRRL B-1445 & L. casei & ATCC 7496 & Flynn \\
\hline 10 & NRRL B-1913 & L. casei & ATCC 11582 & ATCC \\
\hline 11 & NRRL B-1922 ${ }^{a}$ & L. casei & ATCC 393 & ATCC \\
\hline 12 & NRRL B- $4564^{a}$ & L. casei subsp. alactosus & ATCC 27216 & ATCC \\
\hline 13 & NRRL B-4560 & L. casei subsp. pseudoplantarum & ATCC 25598 & ATCC \\
\hline 14 & NRRL B-1041 & L. casei subsp. rhamnosus & ATCC 9595 & ATCC \\
\hline 15 & NRRL B-1914 & L. casei subsp. rhamnosus & ATCC 12116 & ATCC \\
\hline 16 & NRRL B-4561 & L. casei subsp. tolerans & ATCC 25599 & ATCC \\
\hline 17 & NRRL B-4391 ${ }^{a}$ & L. coryniformis subsp. coryniformis & ATCC 25602 & ATCC \\
\hline 18 & NRRL B- $4390^{c}$ & L. coryniformis subsp. torquens & ATCC 25600 & ATCC \\
\hline 19 & NRRL B- $4562^{a}$ & L. curvatus & ATCC 25601 & ATCC \\
\hline 20 & NRRL B-763 ${ }^{a}$ & L. delbrueckii & ATCC 9649 & ATCC \\
\hline 21 & NRRL B-1933 & L. delbrueckii & ATCC 11978 & ATCC \\
\hline 22 & NRRL B-1934 & L. delbrueckii & ATCC 11979 & ATCC \\
\hline 23 & NRRL B-1842 & L. helveticus & ATCC 8018 & ATCC \\
\hline 24 & NRRL B-1937 & L. helveticus & ATCC 11982 & ATCC \\
\hline 25 & NRRL B-4526 ${ }^{a}$ & L. helveticus & ATCC 15009 & ATCC \\
\hline 26 & NRRL B-4559 ${ }^{c}$ & L. homohiochi & ATCC 15434 & ATCC \\
\hline 27 & NRRL B-4550 ${ }^{a}$ & L. jensenii & ATCC 25258 & ATCC \\
\hline 28 & NRRL B- $4525^{a}$ & L. lactis & ATCC 12315 & ATCC \\
\hline 29 & NRRL B-4523 ${ }^{a}$ & L. leichmannii & ATCC 4797 & ATCC \\
\hline 30 & NRRL B-4563 ${ }^{a}$ & L. mali & ATCC 27053 & ATCC \\
\hline 31 & NRRL B- $4496^{a}$ & L. plantarum & ATCC 14917 & ATCC \\
\hline 32 & NRRL B-1950 ${ }^{a}$ & L. salivarius subsp. salicinius, & ATCC 11742 & ATCC \\
\hline 33 & NRRL B-1949 ${ }^{a}$ & L. salivarius subsp. salivarius & ATCC 11741 & ATCC \\
\hline 34 & NRRL B-4538 & L. amylovorus & & Original isolate \\
\hline 35 & NRRL B-4539 & L. amylovorus & & Original isolate \\
\hline 36 & NRRL B-4540 ${ }^{\circ}$ & L. amylovorus & & Original isolate \\
\hline 37 & NRRL B-4542 & L. amylovorus & & Original isolate \\
\hline 38 & NRRL B-4449 & L. xylosus & ATCC 15577 & ATCC \\
\hline 39 & NRRL B- $4565^{a}$ & "L. yamanashiensis"d & ATCC 27304 & ATCC \\
\hline
\end{tabular}

${ }^{a}$ Type strain

${ }^{b}$ American Type Culture Collection.

${ }^{c}$ Reference strain.

${ }^{d}$ Not on the Approved Lists of Bacterial Names (19).

itored in a UV-VIS thermal analyzer system (Gilford Instrument Laboratories, Inc.). A denaturation temperature of $90^{\circ} \mathrm{C}$ was obtained rapidly and held for 10 min after the hyperchromic shift at $260 \mathrm{~nm}$. Subsequently, the temperature was lowered rapidly to $25^{\circ} \mathrm{C}$ below $T_{m}$; the optical density at this point was taken to represent $0 \%$ renaturation (although some undoubtedly occurs). For these studies, the $T_{m}$ values were determined in the presence of $3 \times \mathrm{SSC}$ and $20 \%$ dimethyl sulfoxide. The absorbance change at $260 \mathrm{~nm}$ was monitored until the DNA was more than $50 \%$ reassociated. All determinations were repeated three times. Percent renaturation was calculated by the equation given by Seidler and Mandel (17).
Cell wall analysis. A purified cell wall preparation was made from cells in the mid-log phase. The procedure of Cummins and Johnson (3) was used to disrupt the cells and to purify the cell walls obtained.

To determine the sugar composition, $10 \mathrm{mg}$ of the cell wall preparation was hydrolyzed by heating at $100^{\circ} \mathrm{C}$ for $2 \mathrm{~h}$ in $2 \mathrm{~N} \mathrm{H}_{2} \mathrm{SO}_{4}$. When cooled, the acid was neutralized with $\mathrm{Ba}(\mathrm{OH})_{2}$. After filtration to remove the barium sulfate precipitate, the supernatant was evaporated to dryness. The soluble material was taken up in 0.2 to $0.3 \mathrm{ml}$ of distilled water. The hydrolysates $(25 \mu \mathrm{l})$ were spotted on Whatman no. 1 paper and developed with a butanol-pyridine-water $(60: 40: 30)$ solvent. The sugars were detected with aniline hydro- 
gen phthalate or with alkaline silver nitrate (20).

For amino acid analysis, the cell wall was hydrolyzed by refluxing in $6 \mathrm{~N} \mathrm{HCl}$ for $24 \mathrm{~h}$. Amino acid analysis of the hydrolysates was carried out in a Glenco MM-100 amino acid analyzer.

\section{RESULTS AND DISCUSSION}

The cell walls of all four $L$. amylophilus strains contained the sugars galactose, glucose, glucosamine, mannose, and rhamnose, and the amino acids alanine, aspartic acid, glutamic acid, and lysine. Visual inspection of the paper chromatograms indicated that glucose and galactose were the major sugar components of the cell wall. The average relative molar concentrations of aspartic acid, glutamic acid, lysine, and alanine were $0.37,0.63,0.40$, and 1.0 , respectively.

The amino acid content of $L$. amylophilus cell wall was typical of that of most homofermentative Lactobacillus species. In the cell walls of these organisms, D-aspartic acid and lysine consistently occur as linked moieties in the peptido- glycan $(15,16)$. Aspartic acid acts as the bridge between peptide subunits (16). The equimolar amounts of aspartic acid and lysine found in the cell wall of $L$. amylophilus is what would be expected if these amino acids were linked. Experiments to show linkage of aspartic acid and lysine in L. amylophilus cell wall were not done in this study. In several exceptions, viz., $L$. plantarum, $L$. ruminis, $L$. vitulinis, and " $L$. yamanashiensis" (this name was not on the Approved Lists of Bacterial Names [19], has not been validly published since 1 January 1980 , and hence is without standing in nomenclature), the cell walls contain diaminopimelic acid, which directly cross-links the peptide subunits $(2,16$, 18). No diaminopimelic acid was present in $L$. amylophilus cell walls. The sugar contents of $L$. amylophilus and L. casei walls are similar (15).

Spectrophotometric techniques for determining the degree of DNA-DNA hybridization were discussed both by Seidler and Mandel (17) and by De Ley et al. (4). The $C_{0} t$ technique (21) is the

TABLE 2. DNA reassociation of $L$. amylophilus and species with similar characteristics

\begin{tabular}{|c|c|c|c|c|c|}
\hline \multirow{2}{*}{$\begin{array}{c}\text { Strain } \\
\text { (serial no.) }\end{array}$} & \multirow[b]{2}{*}{ Similarity } & \multicolumn{4}{|c|}{ \% Reassociation ${ }^{a}$ with DNA from $L$. amylophilus } \\
\hline & & $\begin{array}{c}\text { Serial no. } \\
2\end{array}$ & $\begin{array}{c}\text { Serial no. } \\
3\end{array}$ & $\begin{array}{c}\text { Serial no. } \\
4\end{array}$ & $\begin{array}{c}\text { Serial no. } \\
5\end{array}$ \\
\hline 9 & & 13 & 10 & 8 & 10 \\
\hline 10 & & 10 & 15 & 12 & 11 \\
\hline 11 & & 15 & 11 & 12 & 16 \\
\hline 12 & Produce L-(+)-lactic acid, mol\% $\mathrm{G}+\mathrm{C}$ & 15 & 14 & 10 & 11 \\
\hline 13 & & 33 & 22 & 12 & 20 \\
\hline 14 & & 10 & 15 & 11 & 12 \\
\hline 15 & & 12 & 8 & 14 & 18 \\
\hline 16 & & 21 & 14 & 15 & 18 \\
\hline 32 & & 17 & 12 & 15 & 13 \\
\hline 33 & Produce $\mathrm{L}-(+)$-lactic acid & 12 & 10 & 9 & 10 \\
\hline 38 & & 16 & 5 & 13 & 7 \\
\hline 6 & & 8 & 10 & 15 & 6 \\
\hline 7 & & 7 & 9 & 11 & 8 \\
\hline 8 & & 12 & 12 & 10 & 13 \\
\hline 18 & & 11 & 8 & 11 & 11 \\
\hline 20 & Sugar fermentation pattern & 11 & 8 & 11 & 11 \\
\hline 21 & 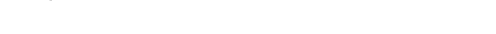 & 8 & 8 & 8 & 10 \\
\hline 22 & & 10 & 12 & 9 & 7 \\
\hline 23 & & 14 & 10 & 13 & 9 \\
\hline 24 & & 15 & 9 & 10 & 10 \\
\hline 25 & & 8 & 10 & 7 & 15 \\
\hline 34 & & 12 & 11 & 13 & 15 \\
\hline 35 & Hydrolyze starch & 10 & 9 & 10 & 9 \\
\hline 36 & & 10 & 9 & 11 & 12 \\
\hline 37 & & 11 & 10 & 10 & 14 \\
\hline 2 & & & 92 & 90 & 95 \\
\hline 3 & Strains & 90 & & 95 & 90 \\
\hline 4 & & 91 & 93 & & 98 \\
\hline 5 & & 94 & 90 & 96 & \\
\hline
\end{tabular}

${ }^{a}$ Average of three determinations. 
basis for Seidler and Mandel's procedure, whereas the initial rate of reassociation concept (7) is the foundation for the method of De Ley et al. The present study employed the method of Seidler and Mandel. Although the membrane filter (6) and hydroxyapatite hybridization procedures (1) may permit somewhat more detailed examination of the DNA relationship involved, the spectrophotometric procedure is a simple, rapid, and reproducible method for distinguishing between species and groups within species (11).

The extent of DNA-DNA interaction between L. amylophilus and species with similar characteristics is recorded in Table 2 . Whenever possible, each species is represented by the type (or reference) strain and several other strains.

Although the four L. amylophilus strains showed some variation in their patterns of sugar fermentation (14), they were closely related genetically, as demonstrated by the high ( 90 to 98\%) DNA reassociation values (Table 2). These strains, however, are not genetically related to L. amylovorus strains (NRRL B-4538, B-4539, B-4540, and B-4552), starch-hydrolyzing lactobacilli isolated from cattle waste-corn fermentations, as was indicated by the low DNA reassociation levels (10 to $15 \%$; see Table 2$)$. Furthermore, L. amylophilus was phenotypically distinguishable from $L$. amylovorus by differences in several characteristics. L. amylophilus produced $\mathrm{L}-(+)$-lactic acid from glucose, had a guanine plus cytosine $(\mathrm{G}+\mathrm{C})$ content of 45.5 mol\%, and grew at $15^{\circ} \mathrm{C}$ but not at $45^{\circ} \mathrm{C}(14)$. In contrast, $L$. amylovorus produces DL-lactic acid, has a $\mathrm{G}+\mathrm{C}$ content of $40.4 \mathrm{~mol} \%$, and grows at $45^{\circ} \mathrm{C}$ but not at $15^{\circ} \mathrm{C}(12)$. The sugar fermentation patterns of these species also differed significantly (13).

L. amylophilus is phenotypically distinct from the other species of Lactobacillus (13). However, similarities of certain selected characteristics suggest that $L$. amylophilus could be related to one of several Lactobacillus species. For example, $L$. amylophilus shares with $L$. casei and its subspecies, both subspecies of $L$. salivarius, and L. xylosus the ability to produce mainly L-(+)lactic acid from glucose $(14,15)$. Moreover, the $\mathrm{G}+\mathrm{C}$ contents of $L$. casei DNA $(46.4 \mathrm{~mol} \%)$ and of $L$. amylophilus DNA (45.5 mol\%) differ only slightly $(14,15)$. The low range of DNA reassociation levels (5 to 33\%) shown in Table 2 indicates that L. amylophilus is not closely related genetically to any of the species or subspecies studied that produce $\mathbf{L}-(+)$-lactic acid.

Similarities of their sugar fermentation patterns suggest a possible relationship of $L$. amylophilus and $L$. bulgaricus, $L$. coryniformis subsp. torquens, $L$. delbrueckii, and $L$. helveticus. Four of these species ferment fructose, galactose, glucose, mannose, and maltose; the fifth, L. bulgaricus, attacks the hexoses but not maltose $(14,15)$. Differentiation from $L$. amylophilus is thus based on the fermentation of sucrose by $L$. delbrueckii, of mannitol and gluconate by $L$. coryniformis subsp. torquens, and of lactose by both $L$. bulgaricus and $L$. helveticus $(14,15)$. None of the four species ferments starch. Furthermore, $L$. amylophilus and $L$. coryniformis subsp. torquens have similar $\mathrm{G}+\mathrm{C}$ contents of about $45 \mathrm{~mol} \%(14,15)$. In spite of these similarities in fermentation patterns, $L$. amylophilus and the four species are not closely related genetically, as indicated by the low yield (6 to $15 \%$ ) of DNA heteroduplex formation (Table 2).

DNA reassociation determinations were also carried out to assess the relationship between $L$. amylophilus and type strains of other homofermentative Lactobacillus species. Reassociation values ranged from a low of $5 \%$ to a high of $18 \%$ for the interaction of DNA from $L$. amylophilus with that of "L. yamanashiensis" B-4565 (serial no. 39) and that of $L$. curvatus B-4562 (serial no. 19), respectively (Table 3 ). These values indicate lack of genetic relationship between $L$. amylophilus and lactobacilli with which it shares no obvious similarities.

Apart from the genotypic homogeneity of the strains assigned to the species $L$. amylophilus, the present study showed an absence of a close genetic relationship between $L$. amylophilus and the other lactobacilli studied. Thus, it is concluded that $L$. amylophilus is a genospecies clearly distinct from the other species. It is also evident that similar fermentation patterns and other physiological characteristics and similar $\mathrm{G}+\mathrm{C}$ ratios are not necessarily indicators of genetic relationship.

TABLE 3. DNA reassociation between $L$ amylophilus and other homofermentative species

\begin{tabular}{|c|c|c|c|c|}
\hline \multirow{2}{*}{$\begin{array}{c}\text { Strain } \\
\text { (serial no.) }\end{array}$} & \multicolumn{4}{|c|}{$\begin{array}{l}\% \text { Reassociation }{ }^{a} \text { with DNA } \\
\text { from } L \text {. amylophilus }\end{array}$} \\
\hline & $\begin{array}{c}\text { Serial no. } \\
2\end{array}$ & $\underset{3}{\text { Serial no. }}$ & $\underset{4}{\text { Serial no. }}$ & $\underset{5}{\text { Serial no. }}$ \\
\hline 1 & 15 & 13 & 9 & 10 \\
\hline 17 & 15 & 11 & 17 & 12 \\
\hline 19 & 18 & 12 & 15 & 19 \\
\hline 26 & 7 & 8 & 7 & 9 \\
\hline 27 & 14 & 12 & 8 & 11 \\
\hline 28 & 8 & 8 & 10 & 9 \\
\hline 29 & 15 & 18 & 17 & 15 \\
\hline 30 & 8 & 8 & 9 & 7 \\
\hline 31 & 17 & 17 & 10 & 15 \\
\hline 39 & 5 & 7 & 7 & 8 \\
\hline
\end{tabular}

${ }^{a}$ Average of three determinations. 


\section{ACKNOWLEDGMENTS}

I thank James F. Cavins for carrying out the amino acid analyses, and Judith Scheppler and James Swezey for their technical assistance.

\section{REPRINT REQUESTS}

Address reprint requests to: Dr. L. K. Nakamura, Northern Regional Research Center, 1815 North University St., Peoria, IL 61604.

\section{LITERATURE CITED}

1. Brenner, D. J. 1975. Deoxyribonucleic acid reassociation in the taxonomy of enteric bacteria. Int. J. Syst. Bacteriol. 23:298-307.

2. Carr, J. G., P. A. Davies, F. Dellaglio, and M. Vescovo. 1977. The relationship between Lactobacillus mali from cider and Lactobacillus yamanashiensis from wine. J. Appl. Bacteriol. 42:219-228.

3. Cummins, C. S., and J. L. Johnson. 1971. Taxonomy of the clostridia: wall composition and DNA homologies in Clostridium butyricum and other butyric acid-producing clostridia. J. Gen. Microbiol. 67:33-46.

4. De Ley, J., H. Cattoir, and A. Reynaerts. 1970. The quantitative measurements of DNA hybridization from renaturation rates. Eur. J. Biochem. 12:133-142.

5. de Man, J. C., M. Rogosa, and M. E. Sharpe. 1960. A medium for the cultivation of lactobacilli. J. Appl. Bacteriol. 23:130-135

6. Denhardt, D. T. 1966. A membrane filter technique for the detection of complementary DNA. Biochem. Biophys. Res. Commun. 23:641-646.

7. Gillis, M., J. De Ley, and M. De Cleene. 1970. The determination of molecular weight of bacterial genome DNA from renaturation rates. Eur. J. Biochem. 12:143153.

8. Mandel, M., and J. Marmur. 1968. Use of ultraviolet absorbance-temperature profile for determining the guanine plus cytosine content of DNA. Methods Enzymol. 12B:195-206.
9. Markov, G. G., and I. G. Ivanov. 1974. Hydroxyapatite column chromatography procedure for isolation of purified DNA. Anal. Biochem. 59:555-563.

10. Marmur, J. 1961. A procedure for the isolation of deoxyribonucleic acid from microorganisms. J. Mol. Biol. 3:208-218.

11. Myers, W. F., and C. L. Wiseman, Jr. 1980. Genetic relatedness among the typhus group of rickettsiae. Int. J. Syst. Bacteriol. 30:143-150.

12. Nakamura, L. K. 1981. Lactobacillus amylovorus, a new starch-hydrolyzing species from cattle waste-corn fermentations. Int. J. Syst. Bacteriol. 31:00-00.

13. Nakamura, L. K. 1981. Lactobacillus amylophilus. In validation of new names and new combinations previously effectively published outside the IJSB. List no. 6. Int. J. Syst. Bacteriol. 31:00-00.

14. Nakamura, L. K., and C. D. Crowell. 1979. Lactobacillus amylophilus, a new starch-hydrolyzing species from swine waste-corn fermentation. Dev. Ind. Microbiol. 20:532-540.

15. Rogosa, M. 1974. Genus I. Lactobacillus, p. 576-593. In R. E. Buchanan and N. E. Gibbons (ed.), Bergey's manual of determinative bacteriology, 8 th ed. The Williams \& Wilkins Company, Baltimore.

16. Schleifer, K. H., and O. Kandler. 1972. Peptidoglycan types of bacterial cells walls and their taxonomic implications. Bacteriol. Rev. 36:407-477.

17. Seidler, R. J., and M. Mandel. 1971. Quantitative aspects of deoxyribonucleic acid renaturation; base composition, state of chromosome replication, and polynucleotide homologies. J. Bacteriol. 106:608-614.

18. Sharpe, M. E., and F. Dellaglio. 1977. Deoxyribonucleic acid homology in anaerobic lactobacilli and in possibly related species. Int. J. Syst. Bacteriol. 27:19-21.

19. Skerman, V. B. D., V. McGowan, and P. H. A. Sneath (ed). 1980. Approved lists of bacterial names. Int. J. Syst. Bacteriol. 30:225-420.

20. Trevelyan, W. E., D. P. Porter, and J. S. Harrison. 1950. Detection of sugars on paper chromatograms. Nature (London) 166:444.

21. Wetmur, J. G., and N. Davidson. 1968. Kinetics of renaturation of DNA. J. Mol. Biol. 31:349-370. 